\title{
ASUPAN LEMAK, AKTIVITAS FISIK DAN KEGEMUKAN PADA REMAJA PUTRI DI SMP BINA INSANI SURABAYA
}

\author{
Fat Intake, Physical Activity and Obesity among Adolescent Girls in SMP Bina Insani Surabaya \\ Jayanti Ayu Praditasari ${ }^{*}$, Sri Sumarmi² \\ ${ }^{1}$ Program Studi S1 Ilmu Gizi, Fakultas Kesehatan Masyarakat, Universitas Airlangga, Kota Surabaya \\ ${ }^{2}$ Departemen Gizi Kesehatan, Fakultas Kesehatan Masyarakat, Universitas Airlangga, Kota Surabaya \\ E-mail: jayanti.ayupraditasari@gmail.com
}

\begin{abstract}
ABSTRAK
Kegemukan (overweight dan obesitas) merupakan penimbunan lemak berlebih yang menyebabkan kelebihan berat badan. Penyakit yang berhubungan dengan kegemukan adalah Diabetes, dislipidemia, hipertensi dan penyakit degeneratif lainnya. Faktor yang memengaruhi kegemukan yaitu pola makan, riwayat keturunan, pola hidup, faktor psikis, lingkungan, individu, serta biologis yang dapat memengaruhi asupan dan pengeluaran energi. Konsumsi makanan dengan tinggi lemak dalam jangka waktu yang panjang dan tanpa ada aktivitas untuk pengeluaran energi dapat meningkatkan risiko terjadinya kegemukan. Tujuan penelitian ini adalah menganalisis hubungan asupan lemak dan aktivitas fisik dengan obesitas pada remaja putri di SMP Bina Insani Surabaya. Desain studi penelitian menggunakan case control dengan pendekatan retrospective. Sampel remaja putri di SMP Bina Insani Surabaya yang diambil sebanyak 32 siswi (16 sampel kontrol dan 16 sampel kasus). Asupan lemak total memiliki tergolong kurang. Asupan Monounsaturated Fatty Acids (MUFA) dan Polyunsaturated Fatty Acids (PUFA) tergolong rendah sedangkan Saturated Fatty Acids (SFA) tergolong tinggi. Hasil analisis hubungan menunjukkan bahwa tidak ada hubungan antara asupan lemak dengan kegemukan $(\rho=0,240)$, namun terdapat hubungan antara aktivitas fisik $\rho=0,006(\mathrm{OR}=9,533$, 95\% CI: 1,847-49,204) dengan kegemukan pada remaja. Aktivitas fisik yang sangat ringan memiliki faktor risiko 9,533 kali lebih besar untuk menyebabkan terjadinya kegemukan dibandingkan dengan aktivitas fisik ringan. Oleh sebab itu, diperlukan peningkatan aktivitas fisik pada remaja putri dengan melakukan olahraga untuk mengurangi risiko kegemukan.
\end{abstract}

Kata kunci: aktivitas fisik, asupan lemak, obesitas, remaja putri, status gizi

\begin{abstract}
Obesity is defined as excessive fat accumulation fat that causes excess weight. Diseases that related with obesity are diabetes, dyslipidemia, hypertension and other degenerative diseases. Factors that affect obesity are dietary factors, history of hereditary, lifestyle, psychological factors, environment, individual, and biological which may influence energy intake and expenditure. Consumption of high fat in a long period without any activity for energy expenditure can increase the risk of obesity. This study was aimed to analyse the correlation between fat intake and physical activity with obesity among adolescent girls in SMP Bina Insani junior high school Surabaya. This study employed a case control study design with a retrospective approach. The research participants were 32 female students in Bina Insani junior high school Surabaya (16 control and 16 case samples). Total fat intake was relatively low. The intake of Monounsaturated Fatty Acids (MUFA) and Polyunsaturated Fatty Acids (PUFA) were low while Saturated Fatty Acids (SFA) were high. There was no correlation between fat intake and obesity $(\rho=0.240)$, but there was a significant correlation between physical activity $\rho=0.006(O R=9.533,95 \%$ CI: 1.847-49.204) with adolescent obesity. The very mild physical activity give a risk as much as 9.533 times greater for developing obesity than the mild physical. Therefore, it is necessary to increase physical activity among adolescent girls by doing sports to reduce the risk of obesity.
\end{abstract}

Keywords: physical activity, fat intake, obesity, female adolescent, nutritional status 


\section{PENDAHULUAN}

Indonesia saat ini sedang menghadapi masalah gizi ganda salah satunya adalah obesitas pada remaja (Shrimpton dan Rokx, 2013). Data Riskesdas tahun 2013 menunjukkan bahwa remaja dengan usia 13-15 tahun memiliki prevalensi overweight dan obesitas sebanyak $8,3 \%$ dan $2,5 \%$. Prevalensi overweight $(8,9 \%)$ dan obesitas $(3,9 \%)$ remaja di kota Surabaya sedikit lebih tinggi dibandingkan dengan prevalensi di Indonesia (Kemenkes RI, 2013a). Penelitian Hanifah dan Nindya (2013) menunjukkan prevalensi gizi lebih pada kelas 7 dan 8 di salah satu SMP di Surabaya mencapai 31\%. Penelitian Nufus (2015) memperlihatkan persentase lemak remaja putri lebih besar dibandingan dengan laki-laki.

Kegemukan merupakan penimbunan lemak berlebih yang menyebabkan kelebihan berat badan (Kemenkes RI, 2012). Salah satu indikator penentuan status gizi yaitu menggunakan Indeks Massa Tubuh (IMT) (Kemenkes RI, 2011). Peningkatan IMT ini dapat menyebabkan risiko tekanan darah tinggi, hipertensi, kolesterol, LDL dan HDL kolesterol dan trigliserida. risiko penyakit menjadi penyerta peningkatan IMT, seperti Penyakit Jantung Koroner, Stroke, penyakit kantung empedu, dan bahkan kanker (Swinburn et al., 2004).

Terdapat berbagai macam faktor yang dapat meningkatkan risiko seseorang mengalami kegemukan. Faktor-faktor tersebut diantaranya pola makan, riwayat keturunan, pola hidup, faktor psikis, lingkungan, individu, serta biologis yang dapat memengaruhi asupan dan pengeluaran energi (Hendra et al., 2016 dan Marcini et al,, 2011)

Lemak adalah salah satu sumber energi bagi tubuh yang berpengaruh terhadap kegemukan pada remaja (Fentiana, 2012). Konsumsi tinggi lemak dalam jangka waktu yang panjang dapat meningkatkan risiko terjadinya kegemukan (gizi lebih dan obesitas) dan meningkatkan berat badan, sehingga kandungan lemak pada makanan perlu diperhatikan (Widodo, 2014). Pemenuhan kebutuhan zat gizi tubuh dipengaruhi oleh pemilihan makanan yang beragam dan seimbang sesuai dengan pedoman gizi seimbang (Kemenkes RI, 2012).

Konsumsi makanan yang berlebih ditambah dengan kurangnya aktivitas fisik menjadi salah satu penyebab terjadinya kegemukan pada remaja putri (Wijayanti, 2013). Aktivitas fisik yang rendah memiliki peluang 3 kali lebih besar menyebabkan kelebihan berat badan dibandingkan aktivitas yang berat (Vertikal, 2012). Tujuan penelitian ini adalah menganalisis hubungan asupan lemak dan aktivitas fisik dengan obesitas pada remaja putri di SMP Bina Insani Surabaya.

\section{METODE}

Penelitian ini merupakan penelitian observasional dengan desain case control yang dilakukan pada bulan Februari hingga Juni 2017. Sampel dalam penelitian ini adalah siswi kelas VII, VIII dan IX di SMP Bina Insani Surabaya tahun 2017/2018.

Proses skrining dilakukan dengan melakukan pengukuran Berat Badan (BB) menggunakan timbangan badan digital dengan ketelitian $0,1 \mathrm{~kg}$ dan Tinggi Badan (TB) menggunakan microtoise dengan ketelitian $0,1 \mathrm{~cm}$. Penilaian status gizi (Z-Score, IMT/U) menggunakan WHO Anthroplus. Nilai Z-Score yang diperoleh dikategorikan berdasarkan SK Kemenkes Nomor: 1995/ MENKES/SK/XII/2010, yaitu normal (-2 $\leq$ Z-Score $<+1)$ yang masuk dalam kelompok kontrol, gemuk/ overweight $(+1 \leq Z$-Score $<+2)$ dan obesitas (Z-Score $>+2)$ dikategorikan dalam kelompok kasus. Sebanyak 16 siswi diambil menjadi sampel diambil secara acak sederhana (simple random sampling).

Data asupan lemak diperoleh untuk mengetahui banyaknya jumlah makanan yang dikonsumsi remaja putri dalam 1 hari menggunakan wawancara dengan kuesioner recall 24 jam. Hasil penilaian asupan lemak dihitung menggunakan Nutrisurvey dengan satuan gram untuk lemak total, lemak jenuh dan tidak jenuh. Nilai total lemak yang didapatkan kemudian dikategorikan berdasarkan Gibson (2005), yaitu kurang $(<77 \%$ AKG) dan cukup ( $\geq 77 \%$ AKG). 
Data aktivitas fisik diperoleh untuk mengetahui kegiatan dan olahraga yang dilakukan remaja putri. Pengukuran aktivitas fisik dilakukan dengan wawancara menggunakan kuesioner APARQ (Adolescent Physical Activity Questionnaire) berupa jenis aktivitas fisik, frekuensi dan durasi yang dilakukan remaja untuk mengetahui olahraga dan aktivitas fisik. Penilaian kemudian diukur dengan rumus Physical Activity Level (PAL) (FAO et al., 2001), yaitu:

$$
P A L=\frac{\sum(P A R \times \text { alokasi waktu setiap aktifitas })}{24 \text { jam }}
$$

Hasil penilaian aktivitas fisik kemudian diklasifikasikan menjadi sangat ringan (PAL $<1,40$ ) dan ringan (PAL $\geq 1,40$ ). Klasifikasi ini digunakan karena hasil aktivitas sampel yang diperoleh tidak ada yang memiliki aktivitas fisik cukup maupun lebih.

Hasil data yang diperoleh kemudian dilakukan analisis univariat dengan analisis cross tabulation yang disajikan data secara deskriptif dengan tabel distribusi frekuensi. Uji hubungan yang dilakukan menggunakan uji Chi-Square. Penelitian ini telah mendapatkan persetujuan dari komisi etik Fakultas Kesehatan Masyarakat Universitas Airlangga dengan nomor 469-KEPK.

\section{HASIL DAN PEMBAHASAN}

Hasil distribusi frekuensi status gizi pada Tabel 1. menunjukkan bahwa separuh remaja putri memiliki status gizi normal $(50 \%)$ dan separuh lainnya mengalami kegemukan $(28,1 \%$ overweight dan $21,9 \%$ obesitas). Status gizi normal digolongkan kelompok kontrol, sedangkan status gizi gemuk dan obesitas digolongkan kelompok kasus.

Faktor yang memengaruhi kegemukan pada remaja salah satunya adalah asupan lemak. Kebutuhan lemak remaja putri pada usia $13-15$

Tabel 1. Distribusi Status Gizi

\begin{tabular}{lcc}
\hline \multicolumn{1}{c}{ Status Gizi } & $\mathbf{n}$ & $\mathbf{\%}$ \\
\hline Normal & 16 & 50,0 \\
Overweight & 9 & 28,1 \\
Obesitas & 7 & 21,9 \\
\hline
\end{tabular}

Tabel 2. Asupan Lemak, MUFA, SFA, PUFA dan Aktivitas Fisik Remaja Putri

\begin{tabular}{lccccc}
\hline \multirow{2}{*}{ Variabel } & \multicolumn{2}{c}{ Kontrol } & \multicolumn{2}{c}{ Kasus } & \multirow{2}{*}{$\boldsymbol{\rho}$ value } \\
\cline { 2 - 5 } & $\mathbf{n}$ & $\mathbf{\%}$ & $\mathbf{n}$ & $\mathbf{\%}$ & \\
\hline Asupan Lemak & & & & & \\
$\quad$ Kurang & 10 & 62,5 & 7 & 43,8 & \\
Cukup & 6 & 37,5 & 9 & 56,3 & 0,240 \\
$\quad$ Total & 16 & 100 & 16 & 100 & \\
MUFA & & & & & \\
$\quad$ Kurang & 15 & 93,8 & 14 & 87,5 & \\
$\quad$ Cukup & 1 & 6,3 & 2 & 12,5 & 0,500 \\
$\quad$ Total & 16 & 100 & 16 & 100 & \\
SFA & & & & & \\
$\quad$ Kurang Baik & 11 & 68,8 & 10 & 62,5 & \\
$\quad$ Cukup Baik & 5 & 31,3 & 6 & 37,5 & 0,500 \\
$\quad$ Total & 16 & 100 & 16 & 100 & \\
PUFA & & & & & \\
$\quad$ Kurang & 16 & 100 & 16 & 100 & \\
$\quad$ Cukup & 0 & 0 & 0 & 0 & - \\
$\quad$ Total & 16 & 100 & 16 & 100 & \\
Aktivitas Fisik & & & & & \\
$\quad$ Sangat Ringan & 3 & 18,8 & 11 & 68,8 & \\
$\quad$ Ringan & 13 & 81,3 & 5 & 31,3 & 0,006 \\
$\quad$ Total & 16 & 100 & 16 & 100 & \\
\hline
\end{tabular}

tahun dalam sehari yaitu sebanyak $20-30 \%$ dari total energi yang dibutuhkan atau sebanyak 71 gram (Kemenkes RI, 2013b). Asam lemak dapat dikelompokkan menjadi asam lemak jenuh (Saturated Fatty Acids (SFA)), asam lemak tak jenuh tunggal (Monounsaturated Fatty Acids (MUFA)) dan asam lemak tak jenuh ganda (Polyunsaturated Fatty Acids (PUFA)).

Berdasarkan hasil analisis pada tabel 2, kelompok kontrol cenderung memiliki asupan lemak total yang lebih rendah dibandingkan dengan kelompok kasus. Hasil menunjukkan bahwa sebanyak 56,3\% sampel pada kelompok kasus memiliki asupan lemak yang cukup atau lebih tinggi dibandingkan kelompok kontrol yang sebagian besar sampel memiliki asupan lemak kurang $62,5 \%$.

Hasil analisis uji hubungan menunjukkan bahwa tidak ada hubungan antara asupan lemak dengan status kegemukan. Penelitian ini menunjukkan hasil yang sejalan dengan penelitian Sasmito (2015) dan Medawati (2005) yang menyatakan bahwa asupan lemak tidak berhubungan dengan status kegemukan pada remaja, namun kontribusi lemak terhadap AKG 
yang semakin tinggi memungkinkan terjadinya kegemukan. Asupan makan merupakan salah satu faktor yang menyebabkan terjadinya kegemukan, namun selain asupan lemak terdapat asupan karbohidrat, protein, konsumsi air dan zat gizi mikro lain yang juga dapat menyebabkan terjadinya obesitas (Marcini et al., 2011; Habibaturochmah dan Fitranti, 2014; Muchlisa et al., 2013). Hewitt-taylor et al., (2004) menyebutkan bahwa selain komposisi asam lemak, kelebihan berat badan dan obesitas dapat dipengaruhi oleh keseimbangan energi dalam tubuh. Selain itu asupan makan dan pengeluaran energi dapat dipengaruhi oleh pola makan, riwayat keturunan, pola hidup, faktor psikis, lingkungan, individu, serta biologis (Hendra et al., 2016 dan Marcini et al., 2011).

Diet tinggi lemak dapat menyebabkan perubahan jaringan adiposa, fungsi mitokondria dan insulin yang berperan dalam komposisi tubuh. Hal tersebut dapat disebabkan oleh jenis asam lemak pada makanan yang memiliki kegunaan berbeda, sehingga perlu untuk mengetahui jenis lemak yang dikonsumsi.

Data yang diperoleh menunjukkan bahwa asupan lemak pada remaja putri pada kelompok kasus maupun kontrol cenderung mengonsumsi lemak jenuh kurang baik. Asupan lemak tidak jenuh pada sebagian besar sampel tergolong rendah (kontrol $=93,8 \%$; kasus $=87,5 \%$ ). Hasil uji hubungan pada MUFA dan SFA tidak memiliki hubungan, sedangkan hasil uji hubungan PUFA tidak dapat dianalisis karena hasil PUFA menunjukan semua remaja putri memiliki asupan yang kurang.

Asam lemak jenuh perlu dibatasi dalam penggunaannya, yaitu sebesar $8 \%$ dari total kalori yang dikonsumsi atau batas konsumsi pada remaja putri sebanyak 18,89 gram. PUFA yang memiliki kandungan n-6 (omega 6) dan n-3 (omega 3) harus dikonsumsi dalam jumlah yang seimbang, yaitu 11 gram dan 1,1 gram pada remaja putri. Rekomendasi batas konsumsi total PUFA yang dikonsumsi oleh remaja sebesar $11 \%$ dari total energi atau sebesar 25,97 gram. Asam lemak tak jenuh tunggal memiliki batas konsumsi yang dihitung dari hasil asupan lemak total dikurangi asam lemak jenuh, asam lemak tak jenuh ganda atau sebesar $11 \%$ dari total energi yaitu sebanyak 25,97 gram (FAO, 2010).

Profil lemak tubuh juga perlu diperhatikan, karena makanan dengan tinggi asam lemak tidak jenuh memiliki profil metabolik yang lebih baik dibandingkan asam lemak yang jenuh (Butryn et al, 2012). Konsumsi lemak tak jenuh dalam jumlah tinggi dengan diimbangi latihan fisik sangat penting dalam penurunan berat badan. Selain itu asam lemak tak jenuh juga dapat meningkatkan sensitivitas insulin dan peningkatan kolesterol HDL sehingga tidak meningkatkan kadar kolesterol atau trigliserida.

Hasil penelitian ini menunjukkan bahwa aktivitas fisik remaja putri di SMP Bina Insani sebagian besar berada pada aktivitas sangat ringan hingga sangat ringan. Kelompok kontrol memiliki aktivitas yang lebih tinggi dari kelompok kasus meskipun masih berada pada aktivitas yang ringan, yaitu sebanyak $81,3 \%$ pada kelompok kontrol dan sebanyak $68,8 \%$ pada kelompok kasus dalam kategori sangat ringan. Hasil analisis hubungan yang dilakukan juga menunjukkan bahwa aktivitas fisik memiliki hubungan dengan status kegemukan. Penelitian ini menunjukkan hasil yang sejalan dengan penelitian Restuastuti et al. (2016) dan Musralianti et al. (2016).

Aktivitas fisik merupakan perilaku positif sebagai pengontrol keseimbangan energi, setiap gerakan tubuh yang menyebabkan peningkatan, pengeluaran, atau pembakaran tenaga. Aktivitas fisik yang ringan pada masa remaja akan cenderung kurang aktif pada masa berikutnya (ACSM, 2015). Hal tersebut merupakan salah satu faktor yang menyebabkan obesitas (Wijayanti, 2013).

Hasil aktivitas fisik yang didapatkan dalam penelitian juga menunjukkan bahwa remaja putri cenderung menghabiskan waktunya untuk menonton TV dan bermain gadget. Pergeseran gaya hidup di daerah pedesaan yang sebelumnya memiliki aktivitas gerak yang lebih banyak menjadi berkurang (Wulandari et al., 2015). Kemajuan teknologi yang berkembang pesat memengaruhi gaya hidup perkotaan yang semakin sibuk dengan gadget daripada bermain bersama teman sebaya diluar.

Latihan fisik dan adaptasi otot pada remaja dapat membantu menurunkan berat badan dan 
Tabel 3. Hasil Analisis Multivariat dengan Chi-Square

\begin{tabular}{lllll}
\hline \multirow{2}{*}{ Variabel } & \multirow{2}{*}{$\boldsymbol{\rho}$ value } & \multirow{2}{*}{ OR } & \multicolumn{2}{c}{$\mathbf{9 5 \%}$ CI } \\
\cline { 3 - 5 } & & & Lower & Upper \\
\hline Aktivitas Fisik & & Pembanding & & \\
Ringan & & 9,533 & & \\
Sangat Ringan & 0,006 & & 1,847 & 49,204 \\
\hline
\end{tabular}

mencegah terjadinya kenaikan berat badan. Aktivitas fisik tinggi akan memecah energi dalam cadangan lemak untuk digunakan, namun aktivitas yang rendah akan semakin menumpuk cadangan lemak dalam tubuh yang dapat menyebabkan peningkatan berat badan (Coelho et al., 2011).

Hasil uji hubungan yang dilakukan juga menunjukkan bahwa aktivitas fisik memiliki hubungan dengan status gizi. Berdasarkan Tabel 3. diperoleh hasil analisis besar risiko (Odds Ratio) menunjukkan nilai $\mathrm{OR}=9,533 \mathrm{CI}$ : 1,847-49.204 yang artinya remaja dengan aktivitas sangat ringan memiliki faktor risiko 9,533 kali lebih tinggi untuk mengalami kegemukan dibandingkan dengan aktivitas fisik ringan.

Keterbatasan penelitian tidak meneliti asupan makan secara makro dan mikro lainnya. Penelitian lebih lanjut disarankan untuk menambahkan variabel lain yang berhubungan dengan kegemukan pada remaja seperti, kebiasaan jajan, konsumsi junk food dan makanan cepat saji.

\section{KESIMPULAN DAN SARAN}

Asupan lemak total remaja putri di SMP Bina Insani cenderung lebih rendah bila dibandingkan dengan kebutuhannya. Dilihat dari jenis lemak yang paling banyak dikonsumsi oleh sampel. Total asupan lemak maupun jenis lemak yang dikonsumsi tidak memiliki hubungan yang signifikan dengan kejadian kegemukan pada remaja putri di SMP Bina Insani.

Remaja dengan aktivitas fisik yang sangat ringan memiliki risiko 9,533 kali lebih besar untuk mengalami kegemukan dibanding remaja dengan aktivitas fisik yang ringan.

\section{PERSANTUNAN}

Penulis mengucapkan terimakasih kepada SMP Bina Insani Surabaya yang telah mengizinkan penelitian, wali murid yang telah mengizinkan siswi berpartisipasi, guru-guru dan Kepala Sekolah SMP Bina Insani Surabaya yang telah membantu teknis pelaksanaan penelitian.

\section{DAFTAR PUSTAKA}

ACSM. (2015). Physical activity in children and adolescents. American College of Sports Medicine, 1-2. Diakses dari: https://www.acsm. org/docs/default-source/brochures/physicalactivity-in-children-and-adolescents.pdf.

Butryn, M.L., Clark, V.L. \& Coletta, M.C. (2012). Behavioral approaches to the treatment of obesity. In S. R. Akabas, S. A. Lederman \& B.J. Moore, eds. Textbook of Obesity: Biological, Phychological and Cultural Influences. United Kingdom (UK): Wiley Blackwell, John Wiley \& Sons, 153-272.

Coelho, D.F., Pereira-Lancha, L.O., Chaves, D. S., Diwan, D., Ferraz, R., Campos-Ferraz, P. L., Poortmans, J. R. \& Lancha, A. H. (2011). Effect of high-fat diets on body composition, lipid metabolism and insulin sensitivity, and the role of exercise on these parameters. Brazilian Journal of Medical and Biological Research, 44(10), 966-972.

FAO, WHO \& UNU, (2001). Human energy requirements, Available at: http://www.fao. org/3/a-y5686e.pdf.

FAO. (2010). Fats and fatty acids in human nutrition (report of an expert consultation). Rome: Food and Agriculture Organization of The United Nations, 66.

Fentiana, N. (2012). Asupan lemak sebagai faktor dominan terjadinya obesitas pada remaja (16-18 tahun) di Indonesia tahun 2010 (Data Riskesdas 2010). Thesis. Universitas Indonesia.

Gibson, R.S. (2005). Principles of nutritional assessment: second edition, Oxford University Press: Oxford University Press.

Habibaturochman \& Fitranti, D.Y.(2014). Hubungan konsumsi air, asupan zat gizi dan aktivitas fisik dengan persen lemak tubuh pada remaja putri. Journal of Nutrition College, 3(4), 595-603. Diakses dari: https://media.neliti.com/media/ publications/93988-ID-hubungan-konsumsiair-asupan-zat-gizi-da.pdf.

Hanifah, N. \& Nindya, T.S. (2013). Hubungan kontribusi beban glikemik makanan dan aktivitas fisik terhadap kejadian gizi lebih pada remaja di SMP full day Surabaya. Media Gizi Indonesia, 9(No. 1 Januari-Juni 2013), 66-71. 
Hendra, C., Manampiring, A. \& Budiarso, F. (2016). Faktor-faktor risiko terhadap obesitas pada remaja di Kota Bitung. Jurnal e-Biomedik, 4(1), 2-6.

Hewitt-taylor, J.,Alexander, J. \& Mcbride, J. (2004). Overweight and obesity in children: a review of the literature. institute of health and community studies Bournemouth University. Diakses dari: http://eprints.bournemouth.ac.uk/11685/1/ Childhood_Obesity_28June04.pdf.

Kementrian Kesehatan RI. (2011). Surat Keputusan Menteri Kesehatan Nomor: 1995/MENKES/ SK/XII/2010 tentang Standar Antropometri Penilaian Status Gizi Anak. Diakses dari http:// gizi.depkes.go.id/wp-content/uploads/2011/11/ buku-sk-antropometri-2010.pdf.

Kemenkes RI. (2012). Pedoman pencegahan dan penanggulangan kegemukan dan obesitas pada anak sekolah, Kementerian Kesehatan Republik Indonesia.

Kemenkes RI. (2013a). Pokok-pokok hasil riset kesehatan dasar (Riskesdas) 2013 Provinsi Jawa Timur, Badan Penelitian dan Pengembangan Kesehatan Kementerian Kesehatan Republik Indonesia Tahun 2013.

Kemenkes RI. (2013b). Regulation on recommended dietary allowance of Indonesia (angka kecukupan gizi). Indonesia's Minister of Health. Jakarta: Kementrian Kesehatan Indonesia

Marcini, M., Ordovas, J. \& et al., eds. (2011). Nutritional and metabolic bases of cardiovascular disease, United Kingdom(UK): Wiley-Blackwell.

Medawati, A., Hadi, H. \& Pramantara, I.D.P. (2005). Hubungan antara asupan energi, asupan lemak, dan obesitas pada remaja SLTP di Kota Yogyakarta dan di Kabupaten Bantul. Jurnal Gizi Klinik Indonesia, 1(3), 119-129.

Muchlisa, C., \& Indrisari, R. (2013). Hubungan asupan zat gizi dengan status gizi pada remaja putri di Fakultas Kesehatan Masyarakat Universitas Hasanuddin Makassar Tahun 2013. Media Kesehatan Masyarakat Indonesia, 1-15. Diakses dari: http://repository.unhas. ac.id/bitstream/handle/123456789/5487/ Jurnal MKMI Muchlisa (K21109312). pdf?sequence-1.

Musralianti, F., Rattu, A.J. \& Kaunang, W.P. (2016). Hubungan antara aktivitas fisik dan pola makan dengan kejadian obesitas pada siswa di SMP
Kristen Eben Haezar 1 Manado. Pharmacon Jurnal Ilmiah Farmasi, 5(2), 84-89.

Nufus, S.H. (2015). Aktivitas fisik, asupan lemak dan persen lemak tubuh pada remaja di Kabupaten dan Kotamadya Bogor, Skripsi. Institut Pertanian Bogor.

Restuastuti, T., Jihadi, M. \& Ernalia, Y. (2016). Hubungan pola makan dan aktivitas fisik terhadap obesitas pada remaja di SMA Negeri 5 Pekanbaru. Jom FK, 3(I), 1-20.

Sasmito, P.D. (2015). Hubungan asupan zat gizi makro (karbohidrat, protein, lemak) dengan kejadian Obesitas pada remaja umur 13-15 tahun di Propinsi DKI Jakarta (analisis data sekunder riskesdas 2010). Nutrire Diaita, 7(1), (April 2015), 16-23.

Shrimpton, R. \& Rokx, C. (2013). The double burden of walnutrition in Indonesia. Jakarta: World Bank.

Sumarmi, S., Nindya, T.S., Diana, R. dan Rifky, M.A. (2017). Kadar serum hepcidin dan TNFalfa pada remaja obes sebagai biomarker defisiensi zat besi yang dipicu oleh diet tinggi lemak. Laporan Penelitian. Universitas Airlangga.

Swinburn, B., Caterson, I., Seidell, J.C. \& James W.P.T. (2004). Diet, nutrition and the prevention of excess weight gain and obesity. Public Health Nutrition, 7(1a), 123-146. Diakses dari: http://www.journals.cambridge.org/abstract S1368980004000175.

Vertikal, L.A. (2012). Aktivitas fisik, asupan energi, dan asupan lemak hubungannya dengan gizi lebih pada siswa SD Negeri Pondokcina I Depok Tahun 2012, Skripsi. Universitas Indonesia, Jakarta

Widodo, G.M. (2014). Hubungan antara asupan lemak dengan status gizi pada WUS Suku Madura di Kecamatan Kedungkandang Kota Malang Tahun 2014. Indonesia Journal of Human Nutrition, 1(1), 12.

Wijayanti, D.N. (2013). Analisis faktor penyebab obesitas dan cara mengatasi obesitas pada remaja putri, Skripsi. Universitas Negeri Semarang.

Wulandari, N.W.M., Muniroh, L. \& Nindya, T.S. (2015). Asupan energi dan aktivitas fisik berhubungan dengan Z-Score IMT/U anak sekolah dasar. Media Gizi Indonesia, 10 (1), 51-56. 